\title{
Quality assessment of pellets and briquettes made from glued wood waste
}

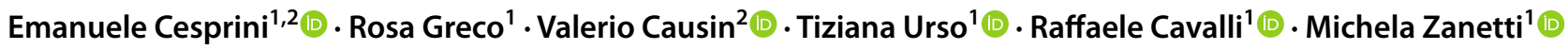

Received: 3 July 2020 / Accepted: 17 March 2021 / Published online: 29 March 2021

(c) The Author(s) 2021

\begin{abstract}
In accordance with sustainable economic and social development, Europe supports the use of energy from renewable sources to decrease the use of fossil fuels. Among renewable energy sources, wood, especially production wood waste from the supply chain, represents an exploitable source in line with a circular economy development. In this context, processing of residues produced by wood companies becomes an important resource. This work deals with the possible energy recovery of glued wood wastes. Two solid biofuels were produced from glued wood wastes: pellets and briquettes. They have been produced in collaboration with a local company and analyzed according to the applicable EN ISO international standards. The results were compared with the limits imposed by the standards in order to identify their quality class and their applicability to the current market. The amount of adhesive present in the wood wastes does not negatively affect the intrinsic characteristics of the material that is suitable for the production of solid biofuels. In addition, the amount of wood waste containing crosslinked polyurethane was calculated in order not to compromise the quality of solid biofuels made therefrom.
\end{abstract}

\section{Introduction}

The need to detach from fossil resources by developing a smart use of renewable ones must be the foundation of the new perspectives to mitigate environmental problems by allowing an economic grow. Different sources of energies, such as solar, wind, geothermal and biomass, can be used in heating systems (Rentizelas et al. 2009). Among them, wind and geothermal energy closely depend on natural conditions. Furthermore, the global capacity of the solar panels has spread rapidly over the past decade which will lead to a significant amount of panels to be disposed (7-8 million tons) by the end of the year 2030, which can significantly increase to an estimated amount of 50-60 million tons by 2050 (Weckend et al. 2016). Contrary to solar or wind energy sources, biomass can be stored and used as needed. Moreover, a reduction in greenhouse gas emissions, greater safety and development of the local economy are some of

Michela Zanetti

michela.zanetti@unipd.it

1 Department of Land, Environment, Agriculture and Forestry, University of Padova, Viale dell'Università 16, 35020 Legnaro, PD, Italy

2 Department of Chemical Sciences, University of Padova, Via Marzolo 1, 35131 Padua, Italy the advantages associated with the use of biomass (Randloev 1997; Pierobon et al. 2015). Combustion, gasification and pyrolysis are the main technologies to create energy from biomass (Frombo et al. 2009). Between them, combustion is the most developed and widely used technology because of its low cost and high reliability (Christoforou and Fokaides 2019; Morales et al. 2013). Nevertheless, overexploitation of natural resources can have negative effects that cannot be missed out. Feeding large plants or supplying entire populations with biomass is hardly sustainable, as we run into the problem of deforestation which, furthermore, negatively afflicts public opinion on the use of wood biomass as biofuel (Upreti 2004). The possibility of using by-products from wood industries is stimulating both from a circular economy perspective and to safeguard the natural heritage.

As reported by the European Directive 2008/98/EC, there is a hierarchical pyramid for the management of waste to be respected by the European countries (European Union 2008). In article 4 of this Directive, 5 steps to be addressed are defined: (a) prevention; (b) preparing for re-use; (c) recycling; (d) another recovery (e.g. energy recovery); and (e) disposal. The open discussion between options (c) and (d) deals with the following question: is it always true that material recycling is preferable to energy recovery? There are many debates on this topic (Hyung and Byul 2014; Rivela 2006; Merrild and Christensen 2009). As reported by Knauf 
(2015), who compares different LCA studies, recycling is not always more convenient than energy recovery. The economic and political framework and the new priorities of European policy (European Union 2009) attached great importance to biomass as an energy carrier, and this aspect is often not considered in the LCA studies as highlighted by Knauf (2015). In addition to the numerous discussions that consider whether energy recovery or recycling of wood waste for the production of new materials is more convenient (Hyung and Byul 2014; Rivela 2006; Merrild and Christensen 2009), there is no legal uniformity between the different countries, both European and non-European.

In this framework, the study aims to take into consideration the inconsistency between some national laws and the international standards on solid biofuels. For example, the problem that afflicts Italian wood companies, unable to exploit an economic return from processing waste, lies in Legislative Decree 152 (2006) which establishes the ban on energy recovery of any chemically treated production waste. Companies are therefore forced to treat potential byproducts, containing small quantities of chemicals, for example, adhesives, as special waste, and consequently to pay for their disposal. The ISO quality specifications of international standards for graded wood pellets EN ISO 17225-2 (2014) and briquettes EN ISO 17225-3 (2014), state that "Negligible levels of glue, grease and other additives used in sawmills during the production of lumber and wood products from virgin wood are acceptable, if all the chemical parameters of the pellets are clearly within the limits and/or the concentrations are too small to be a problem".

To verify the quality of the glued processing waste as solid biofuels, and therefore the actual need for the restrictions in force in some European countries, an exhaustive analysis of production waste, in line with the EN ISO standards, was carried out to assess the quality of the pellets and briquettes made from processing waste. Wood pellets and briquettes are defined by the EN ISO 16559 (2014) as "biofuel made from woody biomass with or without additives in the form of cubiform, polyhedral, polyhydric or cylindrical units, random length and typically $3.15-40 \mathrm{~mm}$, a diameter up to $25 \mathrm{~mm}$ and with broken ends", and "biofuel made with or without additives in the form of cubiform or cylindrical units and a diameter of over $25 \mathrm{~mm}$ produced by compressing pulverised woody biomass", respectively.

\section{Materials and methods}

The wood wastes used to produce pellets and briquettes were supplied by companies located in the Veneto region (Italy). The two different types of wastes were: (i) planer shavings from boards used in Cross Laminated Timber (CLT) production; (ii) planer shavings from solid and laminated wood, and mixed processing waste from solid and glulam wood. In both cases, the wood species was Norway spruce (Picea abies L. Karst).

Both production wastes contained up to $8 \%$ of a monocomponent polyurethane (PU) adhesive, based on aromatic and aliphatic polyisocyanate prepolymers. The percentage of PU glue was estimated following the instructions provided by the CLT manufacturers that use $140 \mathrm{~g} \mathrm{~m}^{-2}$ to assembly 2 wood panel surfaces (corresponding to 1 glue line) and $15 \mathrm{~g}$ of PU for each finger joint. A representative sample of the waste was used to estimate the percentage of adhesive in the solid wood waste. The number and surface of the glue lines and finger joints in the sample were measured and the quantity $(\mathrm{g})$ of adhesive calculated. The percentage of glue was expressed as quantity (g) of glue on the total mass (g) of the sample. Concerning the planer shavings, from an accurate visual check, the presence of glue was not found in the analyzed scraps, but it cannot be excluded that they did not contain adhesive. Considering that planer shavings were also used in the densified biofuels manufacturing, the final amount of adhesive in the waste was not higher than $8 \%$.

In this study, the planing waste of CLT was used to manufacture pellets, while the wood shaving and lamellar processing waste to manufacture briquettes.

According to EN ISO 17225-2 (2014) and EN ISO 17225-3 (2014) international regulations, the critical parameters were analysed, and the quality classes of solid biofuels were defined.

\subsection{Pellets and briquettes production}

The wastes were collected by companies within a week of production, and $168 \mathrm{~kg}$ of planer shavings (average moisture content of $7.5 \pm 1 \%$ ) from Norway spruce CLT boards were used to produce wood pellets at lab-scale. For briquettes manufacturing, $75 \mathrm{~kg}$ of waste was used (average moisture content of $10.7 \pm 2 \%$ ). The quantity of material used for the characterization of the briquettes was $15-20 \mathrm{~kg}$, an amount suitable for carrying out all the tests required by the standards.

The pellets were manufactured in collaboration with $\mathrm{La}$ Meccanica company (Italy) using the planing scraps of Norway spruce boards produced by Artuso Legnami company (Italy), with a CLM 304 E LG pelletizer. A $\varnothing 6 \times 36$ die with a $55 \mathrm{~mm}$ working band was used. The power of the pelletizer electric motor was $45 \mathrm{~kW}$. The machine worked at an average of $38 \mathrm{~Hz}$ frequency with a peripheral speed of $4.53 \mathrm{~m} \mathrm{~s}^{-1}$. The cooling system was not present in the pelletizing line. Therefore, the pellets produced were manually cooled on the floor adjacent to the pelletizer. For the pellets production, preliminary grinding of the material was not necessary since the planing waste already showed dimensions suitable for the process (sieve size $4 \mathrm{~mm}$ ). A quantity 
of water was added to the planing scraps to reach a moisture content of $13 \%$, to optimize the pelletizing process. As reported in several studies (Labbé et al. 2019; Djatkov et al. 2018), the moisture content of the waste material is a key factor for obtaining a quality pellet, and a moisture content from 8 to $15 \%$ is recommended.

The briquettes were made from the processing waste of the company Bozza Legnami (Italy) using a DI PIÙ Systems machine. The briquetting press uses a mechanical pressing mechanism, reaching a value of pressure exerted in the compression chamber of about $2000 \mathrm{~kg} \mathrm{~cm}^{-2}$. The use of these advanced machines allows to obtain a very high hourly production rate for comparatively lower power consumption. The scraps of solid and glulam wood were first ground and then mixed with planing waste to obtain a homogeneous size.

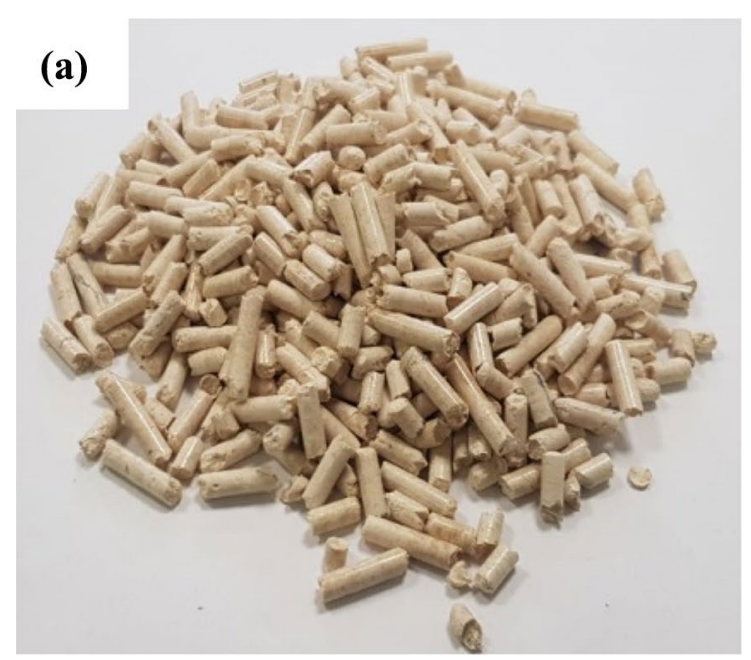

\subsection{Pellets and briquettes characterization}

The pellets and briquettes produced are shown in Fig. 1. The quality characterization was made following the EN ISO methods. The quality parameters and the reference EN ISO standards are reported in Table 1. In particular, the measure of carbon and nitrogen content was made using a modified Dumas method performed with an Elementar Vario Macro Cube. Combustion was performed to convert the samples into ashes and gas. $\mathrm{NO}_{x}$ was reduced to nitrogen. Nitrogen and carbon dioxide contained within the gas stream were assessed quantitatively.

The As, $\mathrm{Cd}, \mathrm{Cr}, \mathrm{Cu}, \mathrm{Hg}, \mathrm{Ni}, \mathrm{Pb}, \mathrm{Si}, \mathrm{Zn}, \mathrm{S}$, and $\mathrm{Cl}$ contents of the biofuels were measured according to the methodology standard (EN ISO 16968 2015). The detection method was the ICP-OES (Arcos EOP, Spectro A. I. GmbH, Kleve,

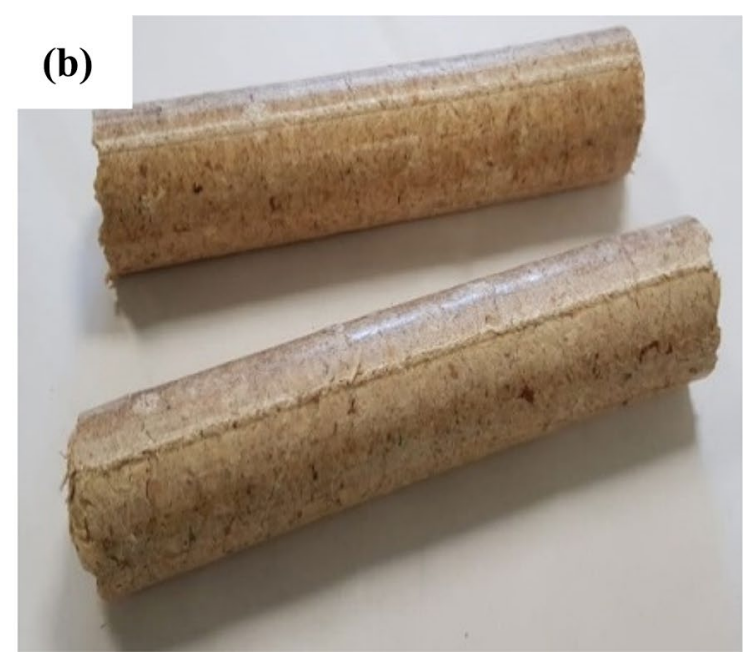

Fig. 1 Solid biofuels produced and analysed in this study: pellets produced from CLT wood scraps (a), and briquettes produced from scraps and X-LAM waste (b)

Table 1 Types of analysis performed for the characterization of biofuel according to legislation

\begin{tabular}{|c|c|c|}
\hline Characteristic & Unit & Reference standard \\
\hline Moisture content & $\mathrm{w}-\%$ as received, wet basis & EN ISO 18134-1 ${ }^{\mathrm{a}, \mathrm{b}}(2017)$ \\
\hline \multirow[t]{2}{*}{ Diameter and length } & $\mathrm{mm}$ & EN ISO 17829a (2015) \\
\hline & & EN ISO $17225-3^{\mathrm{b}}(2014)$ \\
\hline \multirow{2}{*}{$\begin{array}{l}\text { Bulk density } \\
\text { Particle density }\end{array}$} & $\mathrm{kg} \mathrm{m}^{-3}$ as received & EN ISO $17828^{\mathrm{a}}(2015)$ \\
\hline & & EN ISO $18847^{\mathrm{b}}(2016)$ \\
\hline Durability & $\%$ as received & EN ISO $17831^{\mathrm{a}, \mathrm{b}}(2015)$ \\
\hline Ash content & w-\% dry & EN ISO $18122^{\mathrm{a}, \mathrm{b}}(2017)$ \\
\hline Net calorific value & $\mathrm{MJ} \mathrm{kg}^{-1}$ as received & EN ISO $18125^{\mathrm{a}, \mathrm{b}}(2018)$ \\
\hline Ash melting behaviour & ${ }^{\circ} \mathrm{C}$ & EN ISO $21404^{\mathrm{a}, \mathrm{b}}(2020)$ \\
\hline \multirow[t]{2}{*}{ Elemental analysis } & w- $\%$ dry & $\begin{array}{l}\text { EN ISO 16948 } 8^{\mathrm{a}, \mathrm{b}}(2015) \\
\text { EN ISO } 16994^{\mathrm{a}, \mathrm{b}}(2016)\end{array}$ \\
\hline & $\mathrm{mg} \mathrm{kg}^{-1}$ dry & EN ISO $16968^{\mathrm{a}, \mathrm{b}}(2015)$ \\
\hline
\end{tabular}

${ }^{\text {a }}$ Standard references for the characterization of pellets

${ }^{\mathrm{b}}$ Standard references for the characterization of briquettes 
Germany) and the samples were digested using 4 parts of hydrogen peroxide (30\% w/w) and 6 parts of nitric acid $(65 \%$ $\mathrm{w} / \mathrm{w})$. As allowed by the above-mentioned standard, hydrofluoric acid was omitted.

For each investigated characteristic, the analyses were repeated as many times as indicated in the respective EN ISO regulations. The repeatability of each measure was validated according to the EN ISO standard indications.

In addition to the characterization of pellets and briquettes, the planing scraps of the jointed boards were also analysed. The adhesive application involves two steps of the CLT manufacturing process: (i) finger joints and edges gluing to form a panel, and (ii) perpendicular panels gluing. After the finger joints gluing, the glued joints are planed to eliminate the excess of glue. This planing waste is composed only of crosslinked PU adhesive. $3 \mathrm{~kg}$ of glued planing waste was collected and its net calorific value, ash content, and ash melting behaviour were measured.

\section{Results and discussion}

\subsection{Pellets characterization}

The results of the physical-mechanical and elemental analysis of pellets are shown respectively in Tables 2 and 3 . The results were compared to the current EN ISO 17225-2 (2014) standard. As reported in Table 2, all the quality parameters, except for the mechanical durability, of pellets met the quality requirement for an A1 class imposed by the EN ISO 17225-2 (2014). The mechanical durability value is $95.8 \%$ and it does not reach the minimum value stated for a B quality class (96.5\%). The durability value is strictly correlated to the pelletizing temperature (Zanetti et al. 2017a) and the cooling method. During the pelletizing process, the temperature reached was $85^{\circ} \mathrm{C}$, too low to allow the achievement of a satisfactory durability value,

Table 2 Physico-mechanical characteristics of pellets produced from planing waste from Norway spruce boards

\begin{tabular}{|c|c|c|c|c|c|}
\hline \multirow[t]{2}{*}{ Characteristic } & \multirow[t]{2}{*}{ Class } & \multirow[t]{2}{*}{ Measured value } & \multicolumn{3}{|c|}{ Reference values of EN ISO 17225-2: 2014} \\
\hline & & & A1 & A2 & $\mathrm{B}$ \\
\hline Moisture content (M) & M10 & $10 \%$ as received & $\mathrm{M} 10 \leq 10$ & & \\
\hline Diameter (D) & D06 & $6.0 \mathrm{~mm}$ & $\begin{array}{l}\text { D06.6 } \pm 1 \\
\text { D08.8 } \pm 1\end{array}$ & & \\
\hline Length (L) & & $13.5 \mathrm{~mm}$ & $3.15<\mathrm{L} \leq 40$ & & \\
\hline Bulk density (BD) & BD650 & $650 \mathrm{~kg} \mathrm{~m}^{-3}$ as received & $\mathrm{BD} 600 \geq 600$ & & \\
\hline Durability (DU) & DU95.0 & $95.8 \%$ & DU97.5 $\geq 97.5$ & DU97.5 $\geq 97.5$ & DU96.5 $\geq 96.5$ \\
\hline Ash (A) & $\mathrm{A} 0.5$ & $0.4 \%$ dry & $\mathrm{A} 0.7 \leq 0.7$ & $\mathrm{~A} 1.2 \leq 1.2$ & $\mathrm{~A} 2.0 \leq 2.0$ \\
\hline Net calorific value $\left(\mathrm{pci}_{\mathrm{M}}\right)$ & - & $16.5 \mathrm{MJ} \mathrm{kg}^{-1}$ & Q $16.5 \geq 16.5$ & & \\
\hline \multirow[t]{4}{*}{ Ash melting behaviour } & SST & $1200^{\circ} \mathrm{C}$ & Indicate temperature & & \\
\hline & DT & $1380{ }^{\circ} \mathrm{C}$ & & & \\
\hline & HT & $1460{ }^{\circ} \mathrm{C}$ & & & \\
\hline & FT & $1470^{\circ} \mathrm{C}$ & & & \\
\hline
\end{tabular}

$S S T$ shrinkage starting temperature, $D T$ deformation temperature, $H T$ hemisphere temperature, $F T$ flow temperature

Table 3 Elements content of pellets produced from planing waste from Norway spruce boards

\begin{tabular}{llclll}
\hline Elements & Unit & Measured value & \multicolumn{4}{l}{ Reference values of EN ISO 17225-2: 2014 } \\
\cline { 4 - 6 } & & & $\mathrm{A} 1$ & $\mathrm{~A} 2$ & $\mathrm{~B}$ \\
\hline Nitrogen, $\mathrm{N}$ & $\%_{\text {dry }}$ & 0.1 & $\mathrm{~N} 0.3 \leq 0.3$ & $\mathrm{~N} 0.5 \leq 0.5$ & $\mathrm{~N} 1.0 \leq 1.0$ \\
Sulfur, $\mathrm{S}$ & $\%_{\mathrm{dry}}$ & 0.01 & $\mathrm{~S} 0.04 \leq 0.04$ & $\mathrm{~S} 0.05 \leq 0.05$ & $\mathrm{~S} 0.05 \leq 0.05$ \\
Chlorine, $\mathrm{Cl}$ & $\%_{\mathrm{dry}}$ & 0.02 & $\mathrm{Cl} 0.02 \leq 0.02$ & $\mathrm{Cl} 0.02 \leq 0.02$ & $\mathrm{Cl} 0.03 \leq 0.03$ \\
Arsenic, $\mathrm{As}$ & $\mathrm{mg} \mathrm{kg}^{-1}$ dry & $<0.7$ & $\leq 1$ & \\
Cadmium, $\mathrm{Cd}$ & $\mathrm{mg} \mathrm{kg}^{-1}$ dry & 0.1 & $\leq 0.5$ & \\
Chrome, $\mathrm{Cr}$ & $\mathrm{mg} \mathrm{kg}^{-1}$ dry & 1.0 & $\leq 10$ & \\
Copper, $\mathrm{Cu}$ & $\mathrm{mg} \mathrm{kg}^{-1}$ dry & 1.2 & $\leq 10$ & \\
Mercury, $\mathrm{Hg}$ & $\mathrm{mg} \mathrm{kg}^{-1}$ dry & $<0.1$ & $\leq 0.1$ & \\
Lead, $\mathrm{Pb}$ & $\mathrm{mg} \mathrm{kg}^{-1}$ dry & 0.6 & $\leq 10$ & \\
Nickel, $\mathrm{Ni}$ & $\mathrm{mg} \mathrm{kg}^{-1}$ dry & 0.6 & $\leq 10$ & \\
Zinc, $\mathrm{Zn}$ & $\mathrm{mg} \mathrm{kg}^{-1}$ dry & 11.6 & $\leq 100$ & \\
\hline
\end{tabular}


which is obtained when the glass transition temperature of the lignin of $90-100{ }^{\circ} \mathrm{C}$ is reached. As reported earlier (Stelte et al. 2012; Irvine 1985), the glass transition of lignin ranges between $60-95{ }^{\circ} \mathrm{C}$ for moist wood and $160{ }^{\circ} \mathrm{C}$ for dry wood. The durability value is also correlated to the cooling method. As specified before, in this laboratory-scale manufacturing process, it was not possible to use an "industrial" cooling system, such as through insufflation of cold air, and the pellets have been cooled in contact with the floor. Another parameter depending on the manufacturing process is bulk density (Larsson and Rudolfsson 2012). A percentage of the adhesive inside the planing waste seems not to influence the value of bulk density, as reported by several studies (Juan and Gonz 2020; Bartocci et al. 2018; García et al. 2018). The moisture content, the particle size, and the operating characteristics (pressure and temperature) of the pelletizer are the main parameters influencing the bulk density. During densified biofuel manufacturing, moisture content and particle size are inversely proportional to bulk density, while pressure and temperature are directly proportional to bulk density (García et al. 2019). The bulk density value of produced pellets was $650 \mathrm{~kg} \mathrm{~m}^{-3}$, satisfying the limit set by the standard EN ISO 17225-2 (2014). For the other parameters shown in Table 2, however, the intrinsic characteristics of the material and the pellets storage affect the final values recorded (Zanetti et al. 2017b). One of the most critical parameters of solid biofuels is the ash content, both because a high production could cause a problem to the furnace and for their subsequent disposal. By comparing the values of the pellet produced from the waste with the typical values of a coniferous pellet, table B.1, annex B of the EN ISO 17225-1 (2014), it is deduced that the amount of adhesive in the planing waste does not negatively affect most of the classification parameters. The average ash value for a coniferous biomass (without or with insignificant amounts of bark, leaves and needles) is $0.3 \%$ with a variability between 0.1 and $1 \%$, a value which is only depleted by 0.1 units from the ashes of the pellet sample produced from the planing waste. The ash produced by the combustion of the pellets also is less than the maximum value for the quality class A1 (0.7\%). Indeed, by simulating the behaviour of the ashes during combustion through the ash melting test, the deformation temperature (DT), that provides the value at which the first signs of melting occur, is comparable to that of virgin wood. In addition, the net calorific value, that indicates the amount of energy obtainable from a $\mathrm{kg}$ of material as received, is also shown in Table 2. The value (16.5 $\mathrm{MJ} \mathrm{kg}^{-1}$ ) is within the limit imposed by the standard to classify the pellets as an A1 quality class. As reported in table B.1, annex B of EN ISO 17225-1 (2014), the average reference value of the net calorific value (dry basis) for a coniferous biomass (without or with insignificant amounts of bark, leaves and needles) is $19.1 \mathrm{MJ} \mathrm{kg}^{-1}$ with a variability from 18.5 to $19.8 \mathrm{MJ} \mathrm{kg}^{-1}$. The net calorific value of pellets produced form planing waste at $0 \%$ of moisture content is $20 \mathrm{MJ} \mathrm{kg}{ }^{-1}, 0.2 \mathrm{MJ} \mathrm{kg}^{-1}$ higher than the upper limit of typical coniferous biomass reported above. This difference is probably due to the presence of PU adhesive in the pellets. Indeed, the net calorific value of reticulated PU resin, at $0 \%$ of moisture content, is $24.6 \mathrm{MJ} \mathrm{kg}^{-1}$. Concerning the ashes, the measured ash content of PU is $1.5 \%$ and that of pellet containing $8.4 \%$ of adhesive is $0.4 \%$ (Table 2). As reported in Table 2, the limit ash content for the best quality classes (A1 and A2) is respectively 0.7 and $1.2 \%$. Assuming to burn $100 \mathrm{~g}$ of waste, 0.3 and $0.8 \mathrm{~g}$ represent the difference between the measured ash $(0.4 \mathrm{~g})$ and the limits for the A1 and A2 quality classes. If $100 \mathrm{~g}$ of PU produces $1.5 \mathrm{~g}$ of ash, then to produce 0.3 and $0.8 \mathrm{~g}$ of ash, respectively 20 and $53 \mathrm{~g}$ of PU waste are necessary and could be added to planing CLT waste. However, the presence of a high amount of PU waste could negatively influence the ash melting behavior. Normally, to describe the ash melting behavior the deformation temperature (DT) is considered. The DT of PU waste is $890{ }^{\circ} \mathrm{C}$ against $1380{ }^{\circ} \mathrm{C}$ for CLT waste.

To determine whether a pellet sample belongs to an ISO quality class, its elementary analysis is mandatory (EN ISO 17225-2 2014). The results are shown in Table 3. The pellets produced from planing scraps of Norway spruce boards is a A1 class pellet as regards the chemical characterization, proved to be of better quality compared to, for example, solid biofuels produced from not chemically treated biomass waste (Zanetti et al. 2017a). The only chemical treatment to which Norway spruce boards were subjected was bonding with polyurethane adhesive $\left(140 \mathrm{~g} \mathrm{~m}^{-2}\right)$. For this reason, the element, which most interest was focused on, was nitrogen. However, as shown in Table 3, the amount of resin is not enough to make nitrogen exceed the A1 limit concentration $(0.3 \%)$. The other elements, such as chlorine, sulfur, and heavy metals, as expected, showed concentrations within the limits imposed by the standards. The use of wood without bark and the absence of other wood treatments such as the addition of preservatives, paints, organic additives led to chemical parameters in line with virgin wood.

\subsection{Briquettes characterization}

Tables 4 and 5 show the results of the physical-mechanical and elemental characterization of the briquettes. The values obtained from laboratory tests make the briquettes fall into the highest quality class: A1. In this case, for mechanical durability and dimensions, there are no limits to be respected, only the value must be indicated. However, the 
Table 4 Physico-mechanical characteristics of briquettes produced from solid and laminated wood planing shavings and solid and lamellar processing waste

\begin{tabular}{|c|c|c|c|c|c|}
\hline \multirow[t]{2}{*}{ Characteristic } & \multirow[t]{2}{*}{ Class } & \multirow[t]{2}{*}{ Measured value } & \multicolumn{3}{|c|}{ Reference values of EN ISO 17225-3: 2014} \\
\hline & & & A1 & A2 & B \\
\hline Moisture content $(\mathrm{M})$ & M12 & $10.7 \%$ as received & $\mathrm{M} 12 \leq 12$ & $\mathrm{M} 15 \leq 15$ & $\mathrm{M} 15 \leq 15$ \\
\hline Diameter (D) & & $50.0 \mathrm{~mm}$ & \multicolumn{3}{|c|}{ Indicate diameter, width and length } \\
\hline Length (L) & & $321.7 \mathrm{~mm}$ & & & \\
\hline Density (DE) & DE 1.0 & $1.2 \mathrm{~g} \mathrm{~cm}^{-3}$ as received & DE $1.0 \geq 1.0$ & DE0.9 $\geq 0.9$ & DE0.9 $\geq 0.9$ \\
\hline Mechanical durability (DU) & DU95.0 & $99.0 \%$ & \multicolumn{3}{|l|}{ Indicate value } \\
\hline Ash (A) & A 1.0 & $0.7 \%$ dry & $\mathrm{A} 1.0 \leq 1.0$ & $\mathrm{~A} 1.5 \leq 1.5$ & $\mathrm{~A} 3.0 \leq 3.0$ \\
\hline Net calorific value $\left(\mathrm{pci}_{\mathrm{M}}\right)$ & - & $17.1 \mathrm{MJ} \mathrm{kg}^{-1}$ & Q $15.5 \geq 15.5$ & Q $15.3 \geq 15.3$ & Q $14.9 \geq 14.9$ \\
\hline \multirow[t]{4}{*}{ Ash melting behaviour } & SST & $1210^{\circ} \mathrm{C}$ & \multirow{4}{*}{\multicolumn{3}{|c|}{ Indicate temperature }} \\
\hline & DT & $1330^{\circ} \mathrm{C}$ & & & \\
\hline & HT & $1440^{\circ} \mathrm{C}$ & & & \\
\hline & FT & $1480{ }^{\circ} \mathrm{C}$ & & & \\
\hline
\end{tabular}

$S S T$ shrinkage starting temperature, $D T$ deformation temperature, $H T$ hemisphere temperature, $F T$ flow temperature

Table 5 Elements content of briquettes produced from solid and laminated wood planing shavings and solid and lamellar processing waste

\begin{tabular}{llclll}
\hline Elements & Unit & Measured value & \multicolumn{3}{l}{ Reference values (EN ISO 17225-2: 2014) } \\
\cline { 4 - 6 } & & & $\mathrm{A} 1$ & $\mathrm{~A} 2$ & $\mathrm{~B}$ \\
\hline Nitrogen, $\mathrm{N}$ & $\%_{\text {dry }}$ & 0.2 & $\mathrm{~N} 0.3 \leq 0.3$ & $\mathrm{~N} 0.5 \leq 0.5$ & $\mathrm{~N} 1.0 \leq 1.0$ \\
Sulfur, $\mathrm{S}$ & $\%_{\text {dry }}$ & 0.01 & $\mathrm{~S} 0.04 \leq 0.04$ & $\mathrm{~S} 0.05 \leq 0.05$ & $\mathrm{~S} 0.05 \leq 0.05$ \\
Chlorine, $\mathrm{Cl}$ & $\%_{\text {dry }}$ & 0.01 & $\mathrm{C} 10.02 \leq 0.02$ & $\mathrm{C} 10.02 \leq 0.02$ & $\mathrm{C} 10.03 \leq 0.03$ \\
Arsenic, $\mathrm{As}$ & $\mathrm{mg} \mathrm{kg}^{-1}$ dry & $<0.3$ & $\leq 1$ & \\
Cadmium, $\mathrm{Cd}$ & $\mathrm{mg} \mathrm{kg}^{-1}$ dry & 0.1 & $\leq 0.5$ & \\
Chrome, $\mathrm{Cr}$ & $\mathrm{mg} \mathrm{kg}^{-1}$ dry & 0.8 & $\leq 10$ & \\
Copper, $\mathrm{Cu}$ & $\mathrm{mg} \mathrm{kg}^{-1}$ dry & 5.7 & $\leq 10$ & \\
Mercury, $\mathrm{Hg}$ & $\mathrm{mg} \mathrm{kg}^{-1}$ dry & $<0.07$ & $\leq 0.1$ & \\
Lead, $\mathrm{Pb}$ & $\mathrm{mg} \mathrm{kg}^{-1}$ dry & 0.6 & $\leq 10$ & \\
Nickel, $\mathrm{Ni}$ & $\mathrm{mg} \mathrm{kg}^{-1}$ dry & 0.6 & $\leq 10$ & \\
Zinc, $\mathrm{Zn}$ & $\mathrm{mg} \mathrm{kg}^{-1}$ dry & 18.3 & $\leq 100$ & \\
\hline
\end{tabular}

high durability value (99\%), which gives the material compactness and resistance, should be highlighted.

The study of the production and subsequent classification of briquettes is reported by Stolarski et al. (2013). This work compares the quality of different briquettes produced from wood and non-wood biomass. The results obtained in the present study, in terms of ash and calorific value, the other characteristics were not analysed by Stolarski et al. (2013), are similar to the best briquettes from virgin wood produced, and show a quality far superior to other types of non-wood biomass briquettes (Stolarski et al. 2013).

Another recent study (Chen 2015) reported that the biomass combustion properties were improved by $20 \%$ after densification into solid briquettes. In addition, the emissions of greenhouse gas, $\mathrm{NO}_{x}$ and $\mathrm{SO}_{2}$, decreased by one-ninth, one-fifth, and one-tenth compared to coal (Chen 2015).

As for pellets, the elemental analysis is required by the international standard to define the briquettes quality class. All the elements analyzed fall within the limits, and as for pellets, the presence of polyurethane adhesive does not influence the elements final concentrations, especially of nitrogen, in the briquettes. The greater heterogeneity of the waste material used to produce briquettes increased the concentration of nitrogen by $0.1 \%$, the quantity of adhesive was greater but did not exceed the limit by $0.3 \%$.

As reported by Cesprini et al. (2020), many studies have been carried out for the energy recovery of the wood waste but not all materials are suitable for the production of quality biofuels. Indeed, very heterogeneous materials show issues related to the physico-mechanical quality and exceeding of the concentration limits of some elements, caused by further chemical treatments in addition to the bonding. This causes an increase in harmful emissions during solid biofuels combustion. As reported by Zia et al. (2007), the recycling/recovery possibilities of the polyurethane family are manifold. However, it is important to underline how, due to 
the heterogeneity of the waste and the inability to efficiently separate the adhesive from the material, energy recovery through combustion is very attractive, decreasing the volume of the material by $99 \%$ and consequently decreasing the related disposal problems. In the present study, the quantity of polyurethane adhesive used for gluing the boards does not influence the material related characteristics of the biofuel, causing it to fall into an A1 quality class for non-industrial use.

Considering the results presented and discussed in this study, the use of waste material for the solid biofuels production should be promoted. Other studies point out the importance of not using virgin wood for the production of biofuels. Branislav and Luki (2012) highlight the obsolete and inefficient system of using renewable resources in Serbia. This issue is often the same in other European and world countries, where wasteful use and disposal of biomass as well as deficient appropriate combustion technologies persist too (Jetter and Kariher 2009; Maccarty et al. 2010).

Tumuluru et al. (2011) reported all the most important aspects that a producer ought to consider for solid biofuel production, from the intrinsic characteristics of the biomass, such as origin, moisture content, size, and shape, to the production specifications such as type of plant (pellet mills or briquette press), operating temperature and pressure.

Depending on the biomass feedstock, different percentages of cellulose, hemicellulose, lignin, starch, protein, or fat induce disparate responses to the densification process (Tumuluru et al. 2011). It is possible to determine whether and which type of pre-treatment is necessary, whether the addition of binder is advantageous and finally which type and the related parameters of the densification process. The use of glued wood waste in many cases does not require pre-treatment such as size reduction (planing waste), and low percentages of adhesive could improve the particles adhesion.

Table 6 compares the main technologies and the critical parameters for the production of pellets and briquettes, the data have been extrapolated from Tumuluru et al. (2011) and another recent review by Kpalo et al. (2019). As reported by Mobini et al. (2013) and Sgarbossa et al. (2020), the higher cost in energy consumption and $\mathrm{CO}_{2}$ equivalent emissions for the production of solid biomass (pellets) is due to the drying process. Another process phase that could influence the cost and the environmental impact of densified biofuels is the transport (Pierobon et al. 2015). Bussemaker et al. (2017) affirm that the total transportation cost maybe reduces by $40 \%$ by lowering the moisture content. Furthermore, the feasibility to manufacture solid biofuels starting from already dried waste material is certainly an important economic saving. On the other hand, densified biofuels have higher bulk density that offers advantages in terms of storage, handling, and transportation (Tumuluru et al. 2011).

As regards energy consumption, the technologies proposed in Table 6 (pellet mill and hydraulic press) show similar values, $15-40 \mathrm{~kW}$ ton ${ }^{-1}$ for pellets and $34-77 \mathrm{~kW}^{-1}$ for piston press, while utilizing screw and roller press a higher consumption is requested. Generally, hourly production is on average higher for pellets $\left(2.5-5\right.$ ton $\left.\mathrm{h}^{-1}\right)$ than briquettes made from piston and screw press. Instead, the use of a roller press to manufacture briquettes induces a higher hourly production $\left(5-10\right.$ tons $\left.\mathrm{h}^{-1}\right)$.

To the best of the authors ' knowledge, there are no studies highlighting the advantages of using one solid biofuel over the other. The pellet market is certainly very active for domestic use and world production is far greater than that

Table 6 Comparison between the different pellet and briquette production technologies and the related process parameters (Source: Tumuluru et al. 2011; Kpalo et al. 2019)

\begin{tabular}{|c|c|c|c|c|c|}
\hline & Pellets & \multicolumn{4}{|l|}{ Briquettes } \\
\hline Biomass origin & $\begin{array}{l}\text { Wood, agriculture, forest waste, } \\
\text { wood industrial waste }\end{array}$ & \multicolumn{4}{|c|}{ Wood, agriculture, forest waste, wood industrial waste } \\
\hline Typical moisture content (\%) & $10-15$ & \multicolumn{4}{|l|}{$10-20$} \\
\hline Typical particle size (mm) & $<3$ & \multicolumn{4}{|l|}{$6-12$} \\
\hline Addition of binder & Not request & \multicolumn{4}{|l|}{ Not request } \\
\hline Typical shape & Cylindrical & \multicolumn{4}{|l|}{ Cylindrical } \\
\hline \multirow[t]{3}{*}{ Densification system } & Pellet mill & \multicolumn{4}{|c|}{ Briquette press } \\
\hline & & \multicolumn{2}{|l|}{ Piston press } & Screw press & Roller press \\
\hline & & Mechanical & Hydraulic & & \\
\hline Unit densities $\left(\mathrm{g} \mathrm{cm}^{-3}\right)$ & $1.1-1-2$ & $>1$ & $<1$ & $1-1.4$ & n.a. \\
\hline Energy consumption $\left(\mathrm{kW}\right.$ ton $\left.^{-1}\right)$ & $15-40$ & n.a. & $37-77$ & $37-150$ & $30-83$ \\
\hline Production capacity (ton $\mathrm{h}^{-1}$ ) & $2.5-5$ & $0.2-2.5$ & $0.05-0.4$ & $0.5-1$ & $5-10$ \\
\hline Maintenance & Low & High & & Low & Low \\
\hline Output from machine & Continuous & In strokes & & Continuous & Continuous \\
\hline
\end{tabular}


of briquettes (Goh et al. 2013). However, the production of briquettes for industrial uses should not be underestimated; the possibility of using waste material can have important economic return for producers.

\section{Conclusion}

The present study assessed the potential of waste wood for energy production. The possibility of energy recovery of the glued wood waste is certainly a field of high interest since it would allow local businesses to self-sustain energy in their production cycle. The ultimate purpose of this study was therefore to clarify the importance of the knowledge of the wood waste produced, to be able to exploit economic returns, where it is allowed, in line with the new European policies.

A complete characterization of pellets and briquettes made from glued wood waste was presented. The results of quality parameters were compared with the limits imposed by the applicable international standards for non-industrial use, stricter than those for industrial use. Even if, due to their origin, the analyzed biofuels could fall only in the quality class B, the physico-mechanical and element analyses of the two solid biofuels satisfy the requirements of an A1 class, except for the mechanical durability of pellets. Its low value is due to the non-optimized manufacturing process (lack of an audited cooling system) and is not related to biomass itself. As a matter of fact, the durability of briquettes, manufactured with an optimized production system, meets the quality value set by the applicable standard. Therefore, by optimizing the pellet production process, it will be possible to obtain a higher durability value and bring the pellet back into the best quality class. Furthermore, considering the amount of ashes produced by pellet combustion and solid adhesive waste combustion, it emerged that a percentage of $17 \%$ by weight of adhesive waste can be added without compromising the excellent quality of the biofuel (A1). A percentage of $35 \%$ by weight, on the other hand, can be added so that the pellet ash value falls within the limits of class A2.

The results obtained in this study could represent the starting point for a legislative change in the use of wood waste, containing a certain amount of glue, for energy use. However, their use for the production of solid biofuels must be accompanied by a rigid and programmed control in order to guarantee the quality of the combustion of the final product in terms of emissions and quality of the ashes (quantity, elemental analysis and ash melting behaviour). In this regard, the quality certification of densified biofuels made from this type of biomass should be mandatory. However, further studies are necessary on other wood waste glued with other types of adhesives, such as those based on urea-formaldehyde or melamine. Even if the quality certification of the biofuel is a guarantee of the quality of its combustion, the harmful emissions are never nil. The characterization of the combustion of this type of pellets and briquettes should be deepened to suggest good practices to be followed or modifications to be made to the combustion appliances to make it even safer.

Acknowledgements This work was carried out in the frame of "Competitive repositioning of the wood supply chain" (CORE WOOD) project implemented by Programme under the Regional Competitiveness and Employment Objective (POR Veneto), co-funded by the European Regional Development Fund (ERDF) 2014-2020_axis 1, action 1.1.4.

Funding Open access funding provided by Università degli Studi di Padova within the CRUI-CARE Agreement.

\section{Declarations}

Not applicable.

Open Access This article is licensed under a Creative Commons Attribution 4.0 International License, which permits use, sharing, adaptation, distribution and reproduction in any medium or format, as long as you give appropriate credit to the original author(s) and the source, provide a link to the Creative Commons licence, and indicate if changes were made. The images or other third party material in this article are included in the article's Creative Commons licence, unless indicated otherwise in a credit line to the material. If material is not included in the article's Creative Commons licence and your intended use is not permitted by statutory regulation or exceeds the permitted use, you will need to obtain permission directly from the copyright holder. To view a copy of this licence, visit http://creativecommons.org/licenses/by/4.0/.

\section{References}

Bartocci P, Gianni B, Asdrubali F, Beatrice C, Frusteri F, Fantozzi F (2018) Batch pyrolysis of pellet made of biomass and crude glycerol: mass and energy balances. Renew Energy 124:172-179. https://doi.org/10.1016/j.renene.2017.06.049

Branislav D, Luki T (2012) Possibility of efficient utilization of wood waste as a renewable energy resource in Serbia. Renew Sustain Energy Rev 16:1516-1527. https://doi.org/10.1016/j.rser.2011. 10.017

Bussemaker M, Day K, Drage G, Cecelja F (2017) Supply chain optimisation for an ultrasound-organosolv lignocellulosic biorefinery: impact of technology choices. Waste Biomass Valorization 8(7):2247-2261. https://doi.org/10.1007/s12649-017-0043-6

Cesprini E, Resente G, Causin V, Urso T, Cavalli R, Zanetti M (2020) Energy recovery of glued wood waste-a review. Fuel 262:116520. https://doi.org/10.1016/j.fuel.2019.116520

Chen H (2015) Lignocellulose biorefinery product engineering. In: Chen $\mathrm{H}$ (ed) Lignocellulose biorefinery engineering, 1 st edn. Woodhead Publishing, Cambridge, pp 125-165

Christoforou E, Fokaides PA (2019) Advances in solid biofuels. Green energy and technology. Springer. https://doi.org/10.1007/ 978-3-030-00862-8

Djatkov D, Martinov M, Kaltschmitt M (2018) Influencing parameters on mechanical— physical properties of pellet fuel made from corn harvest residues. Biomass Bioenerg 119:418-428. https://doi.org/ 10.1016/j.biombioe.2018.10.009 
EN ISO 16559 (2014) Solid biofuels-terminology, definitions and descriptions. ISO, Geneva

EN ISO 16948 (2015) Solid biofuels_-determination of total content of carbon, hydrogen and nitrogen. ISO, Geneva

EN ISO 16968 (2015) Solid biofuels-determination of minor elements. ISO, Geneva

EN ISO 16994 (2016) Tracked changes solid biofuels-determination of total content of sulfur and chlorine. ISO, Geneva

EN ISO 17225-1 (2014) Solid biofuels-fuel specifications and classes: general requirements. ISO, Geneva

EN ISO 17225-2 (2014) Solid biofuels-fuel specifications and classes part 2: graded wood pellets. ISO, Geneva

EN ISO 17225-3 (2014) Solid biofuels-fuel specifications and classes part 3: graded wood briquettes. ISO, Geneva

EN ISO 17828 (2015) Solid biofuels—determination of bulk density. ISO, Geneva

EN ISO 17829 (2015) Solid biofuels-determination of length and diameter of pellets. ISO, Geneva

EN ISO 17831 (2015) Solid biofuels-determination of mechanical durability of pellets and briquettes. ISO, Geneva

EN ISO 18847 (2016) Solid biofuels-determination of particle density of pellets and briquettes. ISO, Geneva

EN ISO 18122 (2017) Solid biofuels-determination of ash content. ISO, Geneva

EN ISO 18134-1 (2017) Solid biofuels-determination of moisture content-oven dry method part 2: total moisture-simplified method. ISO, Geneva

EN ISO 18125 (2018) Solid biofuels-determination of calorific value. ISO, Geneva

EN ISO 21404 (2020) Solid biofuels-determination of ash melting behaviour. ISO, Geneva

European Union (2008) Directive 2008/98/EC of the European Parliament and of the council of 19 November 2008 on waste and repaling certain directives. Off J Eur Union 3-30

European Union (2009) Directive 2009/28/EC of the European Parliament and of the council of 23 April 2009 on the promotion of the use of energy from renewable sources and amending and subsequently repealing directives 2001/77/EC and 2003/30/EC. Off J Eur Union 16-62

Frombo F, Minciardi F, Robba M, Rosso F, Sacile R (2009) Planning woody biomass logistics for energy production: a strategic decision model. Biomass Bioenerg 33(3):372-383. https://doi.org/10. 1016/j.biombioe.2008.09.008

García R, Pevida C, Rubiera F (2018) Pelletization properties of raw and torrefied pine sawdust: effect of co-pelletization, temperature, moisture content and glycerol addition. Fuel 215:290-297. https:// doi.org/10.1016/j.fuel.2017.11.027

García R, Gil MV, Rubiera F, Pevida C (2019) Pelletization of wood and alternative residual biomass blends for producing industrial quality pellets. Fuel 251:739-753. https://doi.org/10.1016/j.fuel. 2019.03.141

Goh CS, Junginger M, Cocchi M et al (2013) Wood pellet market and trade: a global prospective. Biofuels Bioprod Biorefin 7:24-42. https://doi.org/10.1002/bbb

Hyung M, Byul H (2014) Analysis of the global warming potential for wood waste recycling systems. J Clean Prod 69:199-207. https:// doi.org/10.1016/j.jclepro.2014.01.039

Irvine GM (1985) The significance of the glass transition of lignin in thermomechanical pulping. Wood Sci Technol 19:139-149

Jetter JJ, Kariher P (2009) Solid-fuel household cook stoves: characterization of performance and emissions. Biomass Bioenergy 33(2):294-305. https://doi.org/10.1016/j.biombioe.2008.05.014

Juan FP, Gonz WA (2020) Biofuel quality analysis of fallen leaf pellets: effect of moisture and glycerol contents as binders. Renew Energy 147:1139-1150. https://doi.org/10.1016/j.renene.2019.09.094
Knauf M (2015) Waste hierarchy revisited - an evaluation of waste wood recycling in the context of EU energy policy and the European market. For Policy Econ 54:58-60. https://doi.org/10.1016/j. forpol.2014.12.003

Kpalo SY, Zainuddin MF, Manaf LA (2019) A review of technical and economic aspects of biomass briquetting. Sustainability 12:2-30

Labbé R, Paczkowski S, Pelz S, Knappe V, Russ M, Wöhler M (2019) Effect of feedstock particle size distribution and feedstock moisture content on pellet production efficiency, pellet quality, transport and combustion emissions. Fuel. https://doi.org/10.1016/j. fuel.2019.116662

Larsson SH, Rudolfsson M (2012) Temperature control in energy grass pellet production - effects on process stability and pellet quality. Appl Energy 97:24-29. https://doi.org/10.1016/j.apenergy.2011. 11.086

Legislative Decree 152/2006 (2006). http://www.camera.it/parlam/ leggi/deleghe/06152dl.htm. Accessed 3 Apr 2019

Maccarty N, Still D, Ogle D (2010) Fuel use and emissions performance of fifty cooking stoves in the laboratory and related benchmarks of performance. Energy Sustain Dev 14(3):161-171. https://doi.org/10.1016/j.esd.2010.06.002

Merrild H, Christensen TH (2009) Recycling of wood for particle board production: accounting of greenhouse gases and global warming contributions. Waste Manag Res 27:781-788. https:// doi.org/10.1177/0734242X09349418

Mobini M, Sowlati T, Sokhansanj S (2013) A simulation model for the design and analysis of wood pellet supply chains. Appl Energy 111:1239-1249. https://doi.org/10.1016/j.apenergy.2013.06.026

Morales MP, Mun P, Ruiz JA, Jua MC (2013) Biomass gasification for electricity generation: review of current technology barriers. Renew Sustain Energy Rev 18:174-183. https://doi.org/10.1016/j. rser.2012.10.021

Pierobon F, Zanetti M, Grigolato S, Sgarbossa A, Anfodillo T, Cavalli R (2015) Life cycle environmental impact of firewood production-a case study in Italy. Appl Energy 150:185-195. https:// doi.org/10.1016/j.apenergy.2015.04.033

Randloev P (1997) District Heating Handbook. Technical report NEIDK-3394. Miljoecentret Fredericia, Denmark, p 319

Rentizelas A, Tolis AJ, Tatsiopoulos JP (2009) Logistics issues of biomass: the storage problem and the multi-biomass supply chain. Renew Sustain Energy Rev 13:887-894. https://doi.org/10.1016/j. rser.2008.01.003

Rivela B (2006) Life cycle assessment of wood wastes: a case study of ephemeral architecture. Sci Total Environ 357:1-11. https://doi. org/10.1016/j.scitotenv.2005.04.017

Sgarbossa A, Boschiero M, Pierobon F, Cavalli R, Zanetti M (2020) Comparative life cycle assessment of bioenergy production from different wood pellet supply chains. Forests 11:1127. https://doi. org/10.3390/f11111127

Stelte W, Clemons C, Holm JK (2012) Fuel pellets from wheat straw: the effect of lignin glass transition and surface waxes on pelletizing properties. Bioenergy 5:450-458. https://doi.org/10.1007/ s12155-011-9169-8

Stolarski MJ, Szczukowski S, Tworkowski J, Krzy M, Gulczy P (2013) Comparison of quality and production cost of briquettes made from agricultural and forest origin biomass. Renew Energy 57:2026. https://doi.org/10.1016/j.renene.2013.01.005

Tumuluru JS, Wright CT, Hess JR, Kenney K (2011) A review of biomass densification systems to develop uniform feedstock commodities for bioenergy application. Biofuels Bioprod Biorefin 5:683-707. https://doi.org/10.1002/bbb

Upreti BR (2004) Conflict over biomass energy development in the United Kingdom: some observations and lessons from England and Wales. Energy Policy 32:785-800. https://doi.org/10.1016/ S0301-4215(02)00342-7 
Weckend S, Wade A, Garvin A (2016) End of life management: solar photovoltaic panels. Int Energy Agency. https://doi.org/10.2172/ 1561525

Zanetti M, Brandelet B, Marini D et al (2017a) Vineyard pruning residues pellets for use in domestic appliances: a quality assessment according to the EN ISO 17225. J Agric Eng 48:99. https://doi. org/10.4081/jae.2017.612

Zanetti M, Costa C, Greco R, Grigolato S, Aalmo GA, Cavalli R (2017b) How wood fuels' quality relates to the standards: a classmodelling approach. Energies 10:1-14. https://doi.org/10.3390/ en10101455
Zia KM, Bhatti H, Bhatti A (2007) Methods for polyurethane and polyurethane composites, recycling and recovery: a review. React Funct Polym 67:675-692. https://doi.org/10.1016/j.reactfunct polym.2007.05.004

Publisher's note Springer Nature remains neutral with regard to jurisdictional claims in published maps and institutional affiliations. 